\title{
The Praxis of the Wedded Mystic: a Divergent Reading of Easterine Kire's novel When the River Sleeps
}

\author{
Dhanya A.P $P^{1} \&$ Sudakshina Bhattacharya ${ }^{2}$ \\ ${ }^{1}$ Dept of English and Humanities, Amrita School of Arts and Science, Amrita Vishwa \\ Vidyapeetham, India. ORCID: oooo-0oo1-5979-0260 \\ Email: dhanya25ajith@gmail.com
}

2Dept of English and Humanities, Amrita School of Engineering, Coimbatore

Amrita Vishwa Vidyapeetham, India. ORCID: 00oo-0oo1-7032-0737

Email:s_bhattacharya@cb.amrita.edu

\begin{abstract}
The usual prognosis about literature from the North Eastern regions of India invokes a set of linear, preconceived notions about identity questions, cultural and political conflicts, myths, oral traditions and magic realism. This standpoint has been strongly contested by writer, Easterine Kire, who has revealed a veritable and profound consciousness, embedded deeply in the Angami Naga tradition. That there is an intense and significant version of 'mysticism', hitherto unrealized, has been clearly illustrated in her novel When the River Sleeps. The novelist is successful in searing up this notion and illustrating a wonderful vignette of Naga mysticism. Based on Carl Jung's concept of individuation and making of the 'self, the focus of this paper is mainly on the praxis of Kire's protagonist, Vilie, who delves deeper into the realm of the unseen, intuited by centuries of collective unconscious that helps him to savor mystical experiences. The paper seeks to trace the process of Vilie's individuation, from a hunter, to a self wedded man of the forest, a conservationist, redeemer and finally to a mystic. The principles of Jung can be aptly applied to the various stages of his transcendence. Such a study can also help to vindicate the stipulated notions about the Naga people as overtly aggressive, belligerent head hunters and insurgents.
\end{abstract}

Keywords: North Eastern regions, mysticism, Angami Naga, individuation, collective unconscious

A novelty of perception took birth in the announcement of the Hindu Literary Prize for fiction in the month of January 2016 when surpassing renowned writers like Amitav Ghosh, Anuradha Roy and fifty eight other contenders, a writer from Nagaland named Easterine Kire was chosen for the coveted prize for her novel When the River Sleeps. One of the judges, well known critic M Satchidanandan, after the selection process, made a statement, "We looked for the freshness of content, individual style, innovativeness of the work in contributing to the genre and challenging existing conventions" ( Hamid 2016, par.5). Kire's novel that deals with the unknown world of Naga mysticism has proved the above statement correct to the point of perfection. The author claims that When the River Sleeps is her favourite book that took five months of research and two months to write it.

(c) AesthetixMS 2019. This Open Access article is published under a Creative Commons Attribution Non-Commercial 4.0 International License (http://creativecommons.org/licenses/by-nc/4.o/), which permits non-commercial re-use, distribution, and reproduction in any medium, provided the original work is properly cited. For citation use the DOI. For commercial re-use, please contact editor@rupkatha.com. 
Long before the Indian independence, the Nagas had been demanding a separate sovereign nation following their own rules and traditions. Though the Nehru government promised a non interfering policy with the 'highlanders', they approached them with development projects that appeared to be assimilative and neocolonial. The cultural assault was taking place in utter disregard of the sentiments of the Naga people. The main stream India was also kept at bay about the turbulence in these regions- "but for an entire generation of postcolonial Indians, the little wars of the North East remained a distant thunder, a collection of conflict not worth the bother" (Bhaumik 2009, xvii). The AFSPA and their operations were not let out in the media and "the sole encounter of most Indians with this frontier region remained the tribal dancers atop colourful tableaux on Republic Day parades in Delhi” (Bhaumik 2009, xviii). The other side of the story was ignored and not accepted - "The national media reinforce the 'girl-guitar-gun' stereotype of the region's rebellious youth, while politicians and bureaucrats pandered to pre conceived notions and formulate adhocist policies that would never work" (Bhaumik 2009, xviii). The Naga people especially the youth felt that the betrayal strongly and became caught in the ugly nexus of conflict, violence, disillusionment and depression. Temsula Ao, another renowned Naga writer sums this condition in her introduction to her short stories where she says - "Nagaland's story of the struggle for self- determination started with high idealism and romantic notions of nationalism, but it somehow got re-written into one of disappointment and disillusionment because it became the very thing it sought to overcome"(Ao 2014, x).

The writers such as Kire use the power of words to discuss the true condition of Nagaland for which she had to even seek exile. She had realized that their story and their perspective needed to be broadcast because according to her "The Nagas have a very unique and striking identity and they want this to be honoured and respected" (Kire 2018, par.8). She was also perturbed by the gradual loss of culture and heritage and the unscrupulous and systematic methods of cultural theft which catered to project the Naga people and their culture as exotic and museum specimens. She rebelled against this subtle neocolonial exploitation through her writings. In a paper presented in the International Congress of PEN in Norway, 2004 Kire had asserted that,

"the telling of a story is a spiritual exercise that is an integral part of the healing of a people's psychological wounds...Naga literature is facing a dismissive neo-colonial attitude. Their (publishing houses) expectations from the region are very low indeed. It is a stereotyped expectation that Naga writers are capable only of producing politically charged writing or exotic folk literature in mediocre language" (Kire 2004, par.2).

The literature produced by her talks about the struggles that the people underwent also throws light upon the lost culture such as the intense spiritual world of the Naga people as she believes strongly that "Nagas still have a heightened awareness of the spiritual"( Sarma 2016, par.14). She adopted the oral narratives to signify the tradition and the legacy.

"The incorporation of folklore by modern writers is an important manner of documenting the past as it includes a traditional, non-institutionalised part of a culture. It encompasses all knowledge, understanding, values, attitudes, assumptions, feelings and beliefs transmitted by words of mouth or by customary examples" (Brundvand 1978, 57).

Contemporary Naga authors like Easterine Kire have been trying to break open the pre conditioned barriers to an awakening of the authentic cultural space for the Naga people to the 'external' world. Also by being taken into serious academic discourses, her works pose a viable mechanism to retard cultural theft that was becoming rampant. Her novels are thus a definite 
vindication of the preconceived notions and Kire opens up a whole new world of mysticism for the readers. Rather, she has emerged as an embodiment of the centuries of embedded traits of cultural heritage and through her novel, she extols "...the participation mystique of primitive man with the soil on which he dwells, and which contains the spirit of his ancestors"( Jung 1976,321)

She has tried to incorporate this in her writings and therefore it can be said that she has focused on the extraordinary life of the ordinary Naga people and tried to bring it into the limelight for others to know about Nagaland and their philosophy of life. She consciously makes an effort to break out of the stereotypical examinations done by scholars, who focus on exotic, ethnic and anthropological perspectives to study Nagaland and its culture. Kire says she has experienced reviewers looking only for political elements and highly politicized plots in her books. Despite this, the available discourses pinpoint to exactly these ideas, even bringing about comparisons with African and Latin American magic realism. On the contrary, the purview of this paper seeks to probe deeper to look for more intense values that are universal in line with the Jungian philosophy that emphasizes the mystic phenomenon at par with science and logic.

Kire's novel When the River Sleeps has supernatural elements in them, where human beings and spirits operate on the same plane reaffirming Kire's views that both the natural and the spiritual coexist on the same axis. Various practices among the Angami Nagas along with their laws and morals are shown by Kire inorder to draw the attention of the readers to the unexplored paths of Naga culture. She weaves a tapestry of the physical and the spiritual world that brings out the brilliant pattern of happiness and security. Hence, on the readers, the impression created is indeed very deep. Jung feels that any great work of art achieves the renewal of myth, traditions which are archetypal images that emanate from the deep layers of the collective unconscious:

"That is the secret of great art, and of its effect upon us. The creative process, as we are able to follow it at all, consists in the unconscious activation of an archetypal image, and in elaborating and shaping this image into the finished work. By giving it shape, the artist translates it into the language of the present, and so makes it possible for us to find our way back to the deepest springs of life "( Jung 1976,321).

The faith in Kire's culture made her choose writing as she thought it is the best method to preserve as well as propagate the age old traditions and heritage. When questioned about whether her stories can be accepted by wide readership, Kire is confident that "But when you trust me as a storyteller and begin to accept my stories by believing them your faith wills them into visibility" (Kire 2018, par.10). Her winning the prestigious Hindu literary prize for this novel has proved as a redeeming balm against the pain that she and her North East writer brethren had suffered because "Big Indian publishing houses don't think the North East will sell" (Kire, 2012 par.6). According to her the yoke of neocolonialism can be shed by non Nagas, "By creating opportunities for Naga writers and writers in a similar situation to be published and read extensively" (Kire 2004, par.9).

Kire opens up a whole new world of a person imbued with a deep understanding of life and existence through her portrayal of the protagonist Vilie's transcendence from a hunter to a mystic in her novel When the River Sleeps. He is a man untouched by the lures of the world and enchantment of the magic. He himself claims against the evil spirits about his esoteric capacities "Mine is the greater spirit! Depart from me!"(Kire 2014, 84). Etymologically, the word 'Mystic' is borrowed from the Latin word mysticus which means "of undisclosed means" (Webster 1963) and it is also taken from the Greek word mystikós which also means hidden or clandestine. According to the Merriam Webster dictionary, a mystic can be defined as "a follower 
of a mystical way of life or an advocate of a theory of mysticism" ( Webster 1963, def 2) that is "a person who tries to gain religious or spiritual knowledge through prayer and deep thought: someone who practices mysticism"( Gove 1993,def 1).

Through the understanding of an individual's own self, awareness develops about the entire world. It can be depicted as a hunt for the inner spirit: "The psyche is the starting-point of all human experience, and all the knowledge we have gained eventually leads back to it. The psyche is the beginning and end of all cognition. It is not only the object of its science, but the subject also" (Jung 1973, 3081).

A mystic is a person who realizes oneness in everything thereby crossing the material and psychological borders of duality "and he is intensely and supremely happy just so far as he is steeped in it" (Spurgeon 2011,3). It refers to the condition of exploring and discovering; trying and accomplishing an absolute self-mastery or apprehension. Thus it puts an end to the world of fantasy giving rise to a new world of enlightenment. Sri Aurobindo in his book The Synthesis of Yoga has said, "Every such form (actions of individual) tends towards a harmonised complexity and totality which again breaks apart into various channels of special effort and tendency, only to unite once more in a larger and more puissant synthesis." (Aurobindo 1971, 36) We find Vilie at ease with the physical and the spiritual world always retaining his equilibrium of the mind. Thus, he fulfils the conditionality of being a mystic- "Mysticism is characterized by the experience of an unseen reality, a spiritual presence, a numen, or an absolute that is transcendent in that it is identifiable neither with the empirical world as it appears to us in everyday experience and in natural science nor with the finite self considered as such" (Coward 1979, 324) says Harold Coward in his paper titled Mysticism in the Analytical Psychology of Carl Jung and the Yoga Psychology of Patañjali: A Comparative Study. Jung had sensed the occurrence of good and evil forces moving around him, but he believed that the opposing forces can be defeated if the self could rise above them and only that mattered. According to Coward, Jung feels "mysticism plays a large role in this whole process of uniting and balancing the opposing forces within experience". (Coward 1979, 325)

Mysticism is not a novel concept in India and it is accepted that its intuitive nature manifest through instincts. The importance of instincts has been emphasized by Jung (Jung 1976,54). India is a country with a history of numerous sages who lived here and who have at times disclosed about their mystical experience for people's gain: "Mysticism is, in truth a temper rather than a doctrine, an atmosphere rather than a system of philosophy" (Deo 2017, 90-91). What they believed was that by informing people about the benefits of mystical experience, the people can lead a happy life.

Kire's protagonist, Vilie is a happy man, a perfect antithesis of Freudian principles, continually foraging into the interior of the forest that symbolizes the human mind. A mystical path can never be pre determined and this has been explained in the preface to Vol. IV of The Cultural Heritage of India where it says, "all creatures should be permitted to follow their own lines of approach in this [religious] matter, provided they do not transgress the rights of others" (Bhattacharya 2001, 808) .

So Vilie prefers to be a loner, leaving behind his village and comfort of the hearth and begins to dwell in the forest. That becomes his first step towards "coming to self -realization" (Jung 1976, 122). This process has been termed by Jung as individuation. However, he categorically distinguishes between individualism and individuation. According to him, individualism negates collective considerations but stresses on some "supposed peculiarity" (Jung 1976, 122) whereas, individuation means 
“...more complete fulfillment of the collective qualities of the human being..." (Jung 1976, 122). Carl Jung had developed the notion of the 'collective unconscious' to explain about the thought patterns of one's racial and cultural inheritance, which cannot always be recognized by the conscious mind. As a psycho analyst, he had undertaken intensive investigation to come to the conclusion that "...conscious and unconscious are not necessarily in opposition to one another, but complement one another to form a totality, which is the self"( Jung 1976,126).

The collective unconscious is another principal concept that Jung has put forth to explain the nature of psyche. He considers it as tremendously powerful because "This collective unconscious does not develop individually but is inherited. It consists of preexistent forms, the archetypes which can only become conscious secondarily and which give definite form to certain psychic contents" (Jung 1976, 6o).Vilie fits into the world of 'sage' archetype of Jung because he is "seeker of truth" (Woodward 2010, 17). He continues to search the deeper meanings of life embodying the quality of sage who takes journeys "far in search of the next golden nugget of knowledge" (Woodward 2010, 17).

Easterine Kire's novel 'When the River Sleeps' offers an unfolding of a man's encounter against several forces inspired by a mysterious dream. Vilie had frequent dreams about a magic stone that could be retrieved only when the river slept. The dream is based on the popular belief that if a stone is taken from the river when the river is sleeping, the magic stone has the power to offer anything like "cattle, women, prowess in war, or success in the hunt" (Kire 2014,3). Vilie takes it upon himself to accomplish the difficult task and decides to go in search of the magic stone. The whole story is thus a physical pursuit for a stone that is believed to have divine characteristic. Jung's dream theory suggests the idea that dreams divulge more profound meanings if proper analysis is done. According to Jung "dreams are doing the work of integrating our conscious and unconscious lives" (Hurd 2009, par.3), and this process is termed as individuation. Vilie becomes completely focused on his goal, earning admiration, awe as well as envy from those who knew about it, wished for it but were not ready to take the risks involved. With his determination, his conscious self recognizes the myth of the collective unconscious that generates the making of his self:

"The symbols of the process of individuation that appear in dreams are images of an archetypal nature which depict the centralizing process or the production of a new centre of personality" (Jung 1976, 324).

Vilie keeps getting the recurrent dream of the magic stone, each dream indicating certain images that opens up new insight.

"Symbolism is of immense importance in mysticism; indeed symbolism and mythology are, as it were, the language of the mystic"(Spurgeon 2004, par.11). Not just the stone there are many other things like weretiger, powers of witches, river spirits who wander like beautiful women to trap men, seers etc, that act as symbols in this novel that illustrates a new mystical firmament for the non Naga readers as explained by the critic Satchidanandan, "Nagaland was almost unexplored in Indian fiction and the book, with profound symbolism offered an alternate way of life" (Hamid 2016, par.5). The author Easterine Kire in an email written to Dibyajyoti Sarma on account of her novel When the River Sleeps, says, "Members of my generation are familiar with these elements, and many can recognize them from their own cultural knowledge"(Kire 2016, par.8). On the whole, the journey to find the magic stone or heart stone as it is called is full of 
obstacles. Vilie was experiencing what he had heard from his people. In Nagaland, some forests are titled as 'unclean forest' or just 'unclean place'. It is said that people who have crossed by such area come home and fall ill for the reason that the spirits of those forests are spirits of ill-health. People believe that in these places, human children were taken away by spirit children and therefore elders strictly forbade children from going into or near this area;

"The human children would go missing for days and no search party could find them until the spirit children tire of their play and released their new friends. The old women had many stories to tell of the children who were found again. They never seemed any the worse for their escapades. They would say they had been playing a very nice game and been fed berries, roots and even worms" (Kire 2014, 76).

The unclean forest is called so but no one has tried to find out whether the forest by itself is unclean or the vibrations of those who live there make it unclean. Throughout the journey, there are instances that make Vilie weak and he gets confused about continuing his journey. For example on his way to get the heart stone, he meets three brothers and their guide and decides to stay with them for that night. But that night, the guide gets killed by the elder brother and Vilie leaves from there knowing that he will be falsely accused by them.

According to Jung "Every psychological expression is a symbol if we assume that it states or signifies something more and other than itself which eludes our present knowledge." (Jung 1971, par.817). Rivers symbolize movements and meanderings and its need to take rest is unheard of. However, Kire takes us into that world where rivers snatch time for rest and sleep. When the human mind is calm, it will have deeper revelations and when the river is not in action it will be in a state of absorption:

"When the river is asleep, it is completely still. Yet the enchantment of those minutes or hours when it sleeps is so powerful, that it turns the stones in the middle of the river bed into a charm. If you can wrest a stone from the heart of the sleeping river and take it home, it will grant you whatever it is empowered to grant you"(Kire 2014, 3).

The sleeping river mentioned in the novel can be said as a symbolic depiction of Vilie himself because like Vilie it too lies in a state of absorption. Therefore the whole dream can be said as a symbolic representation of Vilie's revelation of his perfect self.

Symbolism manifests in various ways throughout the novel. The heart stone is in fact entitled as charmed stone by the Nagas but the writer desires to call it heart stone because of it symbolizes the desires of the human mind. Besides this central symbol, there are others such as the Kirhupfümia, a minority group of women thought to have the powers to disfigure, to blind a person or to kill the human species just by pointing their finger at them. They reflect envy and jealousy of the human psyche. The widow-spirit is a blend linking the east's ambisexual Naga spirits and Manipur's treacherous market spirits representing cruelty, hatred and cunningness. In the Naga cosmology, transmigration of spirits from one body to another is a deep belief and tiger spirits are referred to frequently in the novel.

"The folk practice of certain men transforming their spirits into tigers was a closely guarded art. Despite the secrecy, most of the villagers knew who were the men who had become weretigers" (Kire 2014, 25-26).

These tigers appear bigger than the normal tiger and unlike the normal tiger, they approach men even if they try to scare them. The weretigers are called as 'Tekhumiavi' in the Angami language and they undergo long processes before they finally get transformed. It is said that the process 
begins with the spirit turning into a smaller animal from the tiger family and most probably a wildcat. It is said that the Angami men whose spirits start turning would behave strangely. They can see things which are not visible to others and they stare at it for a long time. They play their dirty tricks on cattle; pouncing at them and scratching their skin thus making them growl and mewl. It was not just into tigers alone that the men get transformed into. There are cases where they have become giant snakes and even women perform this practice. But once a person undergoes Lycanthropy it is very difficult for him to turn back and live a normal life of a human being as life after this would be a living death:

"Only with great difficulty, and as though you were going through a living death. The spirit is tormented so greatly that the pain itself is a deterrent to those who want to stop being tigers" (Kire 2014, 28).

However, the risks of these strange metamorphoses cannot influence Vilie who embarks on his bold journey of self introspection. Vilie is satisfied as he feels that he has a stable relationship with his surroundings. He is not perturbed by suggestions and advice. "The forest is my wife," (Kire 2014, 7) says Vilie, the protagonist in the novel, When the River Sleeps. He determinedly lives in the forest. Vilie's psyche begins to attain togetherness between his conscious, personal unconscious and his inherited collective unconscious states. He transcends towards "godlikeness" that endows him with the power to know good and evil( Jung 1976,85).

However, conflict is part of a mystic's being and Vilie cannot escape from that. Initially, when Vilie started living in the forest, he had a feeling of loneliness. At such situations, Vilie questions his inner self about his decision to live an isolated life and at certain point of time, he had even thought about going back to the village. The second year of his forest life was also a life of isolation and solitude. Once, while he was constructing a stone wall on the western side of his shed in order to get protected from the western wind, it was then the barrenness of life that he had preferred started hitting him. He was not able to overcome the bleakness. Although it was daytime Vilie takes out his tools and puts them on the shelf. He takes a walk weighing a series of questions popping up on his mind. He didn't know what he wanted in his life. He remembered his village, people and what they did at such times. To avoid the stress in their labour it was a habit amongst the villagers to sing while working and that too in a "call-and-response" manner and when the work gets completed, they are welcomed by the elders and the young ones. Women get busy cooking for their hardworking men who would be approaching home thinking about the evening food and the rest that they deserve. Memories prohibit him from working the next day also. The call of the society was again attracting him and he dangled in a dilemma. Nevertheless, his dreams about the sleeping river continues and his inner conflict paves the ground for union of the personal conscious and the unconscious within him-

“...the conflict with one's own self which for reasons of psychic equilibrium, demands that the deficit be redressed. Whenever a sense of moral inferiority appears, it indicates not only a need to assimilate an unconscious component but also the possibility of such assimilation" (Jung 1976 81).

Kire has placed her novel in the actual setting of a forest, $20 \mathrm{~km}$ away from the village of Kohima which is under protection by the Khonoma Nature Conservation and Tragopan Sanctuary since 1990. Hence, Kire negotiates within the world of her learning and tradition. She grew up listening to her grandmother's stories and also fearing the sound of the gun. She received a modern education but she also had personal experience of the spirit world. In a candid interview to the The Hindu, she has told "I had a spirit child playmate when I was about four" (Kire 2015, 
par 5).It is evident that mystics break fixities of order and conventions. Although believing that he is wedded to the forest, Vilie knows that stagnation may debar introspection and that is why he is ready to explore more. The mystical marriage between him and his forest wife leads him to this understanding -" he thought perhaps this is what marriage is like; with periods when a chasm of loneliness separates the partners leaving each one alone with their own thoughts, groping for answers,"(Kire 2014, 9). Now his mind was clear and he learnt how to deal with loneliness and win over it and thus it was no longer adverse, "In simply accepting that the loneliness would never be eliminated fully, but that one could deal with it by learning to treat it like a companion and no longer an adversary." (Kire 2014, 10)

Mystics have difficulties strewn in their paths to deviate them from the mystic way of life. In Vilie's life too, the death of Seno, the girl he cherished in his heart, posed such a threat. Vilie loved her with all his heart but fate had separated them. She had a spirit encounter which resulted in her death. Vilie suffers but learns that there is something beyond just the physical world. Benig Mauger, Jungian psychoanalyst psychotherapist has stated that for gaining insight into the higher consciousness, suffering and sadness is necessary -"Heartbreak in this sense is a sacred initiation" (Mauger 2008, par. 20) to get a peace of mind he comes to the forest and there he finds his true self and with the passage of time, he forgets Seno's face and proclaims the forest as his wife and remains loyal to her. According to Jung mystical marriages between the 'animus' (masculine energy) and 'anima' (feminine world of love and emotions) is necessary for transcendence of the spirit. Vilie's energy and strength gets redirected to his understanding of himself.

Acceptance of loneliness is a way of life for Vilie. He no longer feels disturbed by his loneliness as he feels he is wedded to the forest. He spends his time in the forest and enjoys his life there. However, it was a step towards "self-alienation" but of pursuing "self-realization"( Jung 1976 , 122). It was his deliberate stance to achieve the state of individuation.

For a mystic, the primary requirement for pursuing a mystical life is "to spend time in silence around other yogis or gurus doing Sadhana" (Cameron 2014, par.2). This clearly shows that Vilie is an inborn mystic and he has all the characteristics such as the quality of sustainability found among mystics. Initiations can be provided by a worthy teacher. Vilie learns from nature how to sustain life and therefore Nature is his guru. Instead of complaining about the things that he doesn't have Vilie learns how to live with the limitations of life available to him. As he says the forest provided him with things that are "providing him with sanctuary when he most needed it; and food when his rations were inadequate. The forest also protected him from the evil in the heart of man" (Kire 2014, 51) .Thus he felt safe in his forest and was most comfortable there. Whenever he went out he longed to come back as he felt that things would go wrong if he stayed away for a long time. He enjoyed the beauty of nature and found peace in it. The forest like any other wife provided him with food and Vilie was grateful for that - "He took some tender leaves of the tree ferns sprouting by the stream. It was good both for man and animal. It went into his pot and he added more salt to the broth. It was soon ready as the tender sterns did not need to be cooked long. Vilie took out a good portion, and kept the rest of the food aside for the evening"(Kire 2014, 81).

Throughout the novel, Vilie professes a detached life. His life is summarized by his acquaintance in these lines -

"Maybe because you are different from the others who have come here before you. Because your spirit is large-hearted and teachable, and because I sensed you would be more amenable to spirit things than the others were." (Kire 2014,108) 
He is the protector of the gwi (mithuns - Bos Frontalis, a Bovine species found in the mountains). He is a selfless and a happy person. There are various instances in the novel which highlights this notion and the best example of this is his caring and love shown towards Ate, the girl he adopts. The creative mind of the writer has worked well here in the portrayal of their love. While readers would expect a love story between the protagonist and Ate but we find Vilie showering fatherly love towards Ate. Vilie saves Ate from her evil sister Zote and even brings her back to life with the help of the heart stone during the encounter with the spirits. More than his own, it was her life that mattered a lot to him and therefore he decides to take her to his village and to give her a family by introducing her to his aunts. However, he does not stay back and before leaving from there, he hands over the hard-earned heart stone to Ate for her protection. In the last chapter of the novel, Ate thus describes Vilie as "the greatest life giving source I ever knew....He was also the kindest man I knew" (Kire 2014, 237). It can be seen that the motive of his life is selfless service and sacrifice that provides him joy and satisfaction. He undergoes terrible and dangerous feats to get the stone from the sleeping river but when he gets it, he never uses it for his benefits but instead uses it to rescue Ate from the verge of death. Though he has risked his life in getting it, he was able to part from it showing that the life in the forest has made him a redeemer himself. His achievement of the state of individuation is complete as his soul had steered clear of " false wrappings of the persona ..."( Jung 1976,123). His spiritual path is now confirmed where the material pleasures have become mere nothingness.

Kire in response to a mail this writer had sent her clearly mentioned that;

"In this work, I am very interested in showing how the two worlds, the physical world and the spiritual world coexist in the Naga universe. I am not just writing about encountering spirits but I am projecting an abiding sense of the reality of the spiritual. I do find this in many of the older Nagas and in myself so it was a wonderful experience to write about it and have these two books (When the River Sleeps and Son of the Thundercloud) received so well. I also believe that when you are open to experiencing the deeper life of the spirit, the things of the material world become less and less attractive or fulfilling. This is one of the messages. The things that ultimately matter are love and compassion for all, kindness, forgiveness, etc" (Kire 2018, par.2)

and truly Vilie emerges as the messenger of the writer's beliefs.

Jung proposes that, "in collective unconsciousness all human beings share a deep level of unconscious mind universally which is hidden beneath the personal psyche" (Varghese and Balasubramanian 2017, par2). The mystic in Vilie was hidden in his psyche and the forest, acting as his guru helped him discover his hidden self. Although a hunter by birth he took up the job of the protector of the forest which shows his deep communion with nature. He protects them as well as finds solace in them. Even when he goes to take the stone from the river, he never wishes for wealth or power but for acquiring knowledge for the benefit of others,

"He wanted to find the sleeping river. He wanted to catch it while it slept and wrest a river - heart - stone from the waters and take it back home with him. But most of all, he wanted the spiritual knowledge that the sleeping river would give him if they found it... Thus he emerges as an elevated soul capable of redeeming other people's miseries" (Kire 2014, 96).

Every mystic acknowledges the workings of the greater spirit behind him. Vilie had the revelation about this while he had to face the spirit of the river, he exclaimed in ecstasy- 
"Sky is my father, Earth is my mother, stand aside death! Kepenuopfu fights for me, today is my day! I claim the wealth of the river because mine is the greater spirit. To him who has the greatest spirit belongs the stone!" (Kire 2014, 103)

The Naga cosmology envisages a happy realm which the Angami Nagas call as Kelhoukevira which means a land where life is good. Vilie creates this Kelhoukevira through his efforts. He attains transcendence of spirit by uniting with the birth spirit and creator of all called as Ukepenuopfi in his language. This union is sacred as the Jungian union of the transcendent spirit with the divine presence.

Greed takes away man's ability to rise higher and this is what happened to the man who had also come in search of the stone. No one knew that Vilie had already given it to Ate and therefore he came searching for Vilie. After a while he started attacking Vilie and stabbed him. Soon after that Vilie's murderer is killed by the tiger spirit showing that when the higher spirit is hurt or disturbed, the culprit would be avenged by the spirit world-

"The killer had been so preoccupied with Vilie that he never saw the tiger until it was too late. Leaping out of the forest, the weretiger pounced on its prey and iron claws ripped into helpless skin" (Kire 2014, 231).

Here what is to be noted is that Vilie never keeps the stone for himself and without any reluctance gives it to Ate. Being a mystic himself, he has detached from the worldly pleasures and therefore he doesn't want the power that the stone could grant him. The journey had helped him to realize his true self and the purpose of his life; "Jung believed, unlike many of his contemporaries, that all the elements of an individual's nature are present from birth, and that the environment of the person brings them out" (Wilken, par.16). After coming back from the adventure of finding the heart stone, Vilie had undergone a transformation, a transformation of psyche becoming the whole; this is why the nature itself came to punish the man who attacked Vilie. After a few days, the villagers discover the mauled and mangled body and believing it to be Vilie's, mourned for him and make a burial to honour his soul. However, Ate doesn't believe in that and though she cannot explain, she knows that "he didn't die in the fight" (Kire 2014, 237). She believes his spirit to be immortal and she asks her husband to repair Vilie's wooden house in the forest. She tells her husband about Vilie as a man far above the ordinary- "Oh yes, he opened up my mind to the possibility of a whole new existence.... We have gone through the valley of the shadow of death together..." (Kire 2014, 239). Neither the mystery of his end can be explained or investigated, nor it calls for pity or sympathy among the readers, because the Jungian 'homunculus' had come to fulfill his mission of helping the suffering souls (Ate in the novel) by liberating her from the cruel grip of her sister Zote.

The mystics from Nagaland are not mere figments of imagination because Kire, the author has written from her own transcendental and supernatural experiences and her cultural traditions. Therefore, Vilie emerges as a strong prototype vindicating dogmas and beliefs that Kire condemns strongly by telling that -"Stereotyping people is one of the biggest violations of their rights as a human” (Sarma 2016, par. 26).

\section{References}

A. (1997). Art, culture and spirituality: A Prabuddha Bharata centenary perspective 1896-1996. Calcutta: Advaita Ashrama, Publ. Dep. 
Ao, T. (2014). These hills called home: Stories from a war zone. New Delhi: Zubaan

Arora, K. (2012, January 09). Big Indian publishing houses don't think the northeast will sell. The Times of India. Retrieved March 23, 2018, from https://timesofindia.indiatimes.com/interviews/Big-Indianpublishing-houses-dont-think-the-northeast-will-sell/articleshow/11415634.cms

Aurobindo, S. (1971). The Synthesis of Yoga (Vol. 20 and 21). Pondicherry: Sri Aurobindo Ashram

Bhattacharya,H.(2001)The Cultural heritage of India. Retrieved February 25, 2018, from http://estudantedavedanta.net/Cultural_Heritage_Vol_IV.pdf

Bhaumik, S. (2009). Troubled Periphery: Crisis of Indias North East (SAGE Studies on Indias North East). Sage Publications.

Brunvand, J. H. (1978). The Study Of American Folklore An Introduction (2nd ed.). New York: Norton

Cameron, Y. (2014, October 02). 7 Things I Learned From Living In A Forest In India. Retrieved April 20, 2018, from https://www.mindbodygreen.com/o-15539/7-things-i-learned-from-living-in-a-forest-inindia.html

Campbell, Joseph.Ed. (1971). The Portable Jung, New York: Viking Penguin

Coward, H. (1979). Mysticism in the Analytical Psychology of Carl Jung and the Yoga Psychology of Patañjali: A Comparative Study. Philosophy East and West, 29(3), 323-336. doi:10.2307/1398935

Deo, S. A. (n.d.). The Moral Philosophy Of Shikshapatri A Social Moral And Cultural Synthesis. Shodhganga, 90-91. Retrieved February 23, 2018, from http://hdl.handle.net/10603/72017

Gove, P. B. (1993). Mystic [Def. 1]. In Websters third new international dictionary of the English language, unabridged: A Merriam Webster. Springfield, MA: Merriam-Webster.

Hamid, Z. (2016, January 16). Lit for Life: The Hindu Prize for 2015 goes to Easterine Kire. Retrieved February 13, 2018, from http://www.thehindu.com/features/lit-for-life/Lit-for-Life-The-Hindu-Prize-for-2015goes-to-Easterine-Kire/article14003138.ece

Hunt-Meeks, S. (1983). The Anthropology of Carl Jung: Implications for Pastoral Care. Journal of Religion and Health,22(3), 191-211. Retrieved from http://www.jstor.org/stable/27505736

Hurd, R. (2009, November). The Dream Theories of Carl Jung. Retrieved July 25, 2019, from https://dreamstudies.org/2009/11/25/carl-jung-dream-interpretation/

Jung, C. G., Hull, R. F., \& Baynes, H. G. (1971). Psychological types. Princeton, NJ: Princeton University Press.

Jung, C. G., Campbell, J., \& HULL, R. F. C. (1976). The Portable Jung. Edited, with an Introduction, by Joseph Campbell. Translated by R.F.C. Hull. (Fifth printing.) (Vol. 6). New York: Penguin Group.

Kire, E. (2014). When the River Sleeps. New Delhi: Zubaan.

Kire, E. (2004). Lecture presented at International Pen Conference in Norway, Tromso. Retrieved March 23, 2018, from http://nagas.sytes.net/ kaka/articles/artoo7.html

Kire, E. (2018, March 22). Message to the author [E-mail interview].

Many-Worded and Many-Souled: Sitting Down With Dr. Easterine Kire [Interview by S. NARANG]. (2018, February 04). Retrieved March 23, 2018, from https://themitpost.com/sitting-down-with-dreasterine-kire/

Mauger, B. (2008, May 21). The Inner Marriage: Love, Heartbreak and the Search for Wholeness. Retrieved April 15, 2018, from http://iahip.org/inside-out/issue-56-winter-2008/the-inner-marriage-loveheartbreak-and-the-search-for-wholeness 
No division between spiritual and physical [Interview by S. Daftuar]. (2015, November 21). The Hindu. Retrieved March 23, 2018, from http://www.thehindu.com/features/lit-for-life/swati-daftuarspeaks-to-easterine-kire-about-when-the-river-sleeps/article7903799.ece

Rowley, R. (1993). Individuation and Religious Experience: A Jungian Approach to O'Connor's "Revelation". The Southern Literary Journal, 25(2), 92-102. Retrieved from http://www.jstor.org/stable/20078073

Sewell, E. (1978). The Jungian Process of Individuation as Structure in "The Painted Bird". The South Central Bulletin, 38(4), 160-163. doi:10.2307/3187392

Spurgeon, C. F. (2004). Mysticism in English literature [EBook \#11935]. Retrieved April 2, 2018, from https://www.gutenberg.org/files/11935/11935-h/11935-h.htm

Spurgeon, C. F. (2011). Mysticism in English literature. Retrieved March 23, 2018, from https://books.google.co.in/books?id=W6d9CgAAQBAJ\&pg=PT6\&lpg=PT6\&dq=and he is intensely and supremely happy just so far as he is steeped in it\&source=bl\&ots=s8GG2-Thic\&sig=_gjzcoV2OYCP7AoXmuYJGrljME\&hl=en\&sa=X\&ved=oahUKEwjEsbe_ltraAhULrI8KHWADCAEQ6AEIKzAB

Sumi, L. (2018, January 20). The Naga World [Personal interview]

Thomas, A. M. (2016, April 09). The Politics Behind Folklore in North East Indian Writings [Web log post]. Retrieved January 22, 2018, from https://ststephensnortheastsociety.wordpress.com/2016/o4/o9/the-politics-behind-folklore-innorth-east-indian-writings/

Varghese, S., \& Balasubramanian, A. (2017). Carl Jung's Archetypes in Malayalam Film: A Case Study on The Film 'Urumi.' SHS Web of Conferences, 33, ooo18. https://doi.org/10.1051/SHSCONF/20173300018

Webster, N. (1963). Mystic [Def. 2]. In New collegiate dictionary. A Merriam-Webster. Springfield, MA: G. \& C. Merriam

Bayne, T., Wilken, P., \& Kreiman, G. (n.d.). The Jungian Model of the Psyche. Retrieved May 24, 2019, from http://journalpsyche.org/jungian-model-psyche/

Woodward, S. R. (2010). A Sequential Sojourn: Visualizing the Quest of the Archetypal Hero(Second ed.). Lulu Com.

Writing Nagaland - A Conversation With Easterine Kire [Interview by D. SARMA]. (2016, April o1). Retrieved March 23, 2018, from http://raiot.in/writing-nagaland-a-conversation-with-easterine-kire/

Dhanya A.P is a Research Scholar in the Department of English and Humanities at Amrita Vishwa Vidyapeetham, Amritapuri. Her areas of research interest are marginal literature and multidisciplinary studies.

Sudakshina Bhattacharya is an Assistant Professor in the Department of English and Humanities at Amrita Vishwa Vidyapeetham, Coimbatore. Her areas of research interest are Indian Literatures from the North East regions of India and Cultural/ interdisciplinary Studies. 